\title{
THE ATTRACTIVE FACTOR IN THE SETTLEMENT OF OPHELIA BICORNIS SAVIGNY
}

\author{
By Douglas P. Wilson, D.Sc. \\ The Plymouth Laboratory
}

Largely as a result of experiments made in $195 \mathrm{I}$, sands were classed as attractive, neutral or repellent (Wilson, I953a); but only after the 1952 experiments had been completed did it become reasonably certain that the sands in which the larvae of Ophelia bicornis Savigny readily settle carry an attractive factor apparently distinct from a repellent one present in sands in which they will not settle (Wilson, I953 $b$ ). Whilst the precise natures of the factors were uncertain, it seemed probable that they both derive from organic activity. The I953 breeding season was devoted to an attempt to obtain more information about the attractive factor.

\section{Methods}

Methods closely followed those used previously. All glassware was cleaned in hot strong sulphuric acid, and similar acid was used in the preparation of the acid-cleaned sands. These were always prepared from Bullhill Bank sand (collected Io June I952) generally a few days, and not more than a few weeks before use, being stored, after cleaning, in distilled water in stoppered bottles. Fertilizations and experiments were mostly in a mixture of Berkefeld-filtered sea waters from the Eddystone or E I and from the Clyde (obtained by the helpful co-operation of the Millport Marine Station, and Mr E. Latham in particular). Occasionally Clyde water was used alone but never Eddystone or E I water alone. Although all fertilizations were not equally successful there was no difficulty in obtaining healthy larvae for all the experiments, as there had been in 1952 on occasions when E I water only was used (Wilson, I953b, p. 220). Throughout this paper 'sea water' means Berkefeld-filtered sea water.

The culture medium used was 'Erdschreiber', similar to that described by Gross (I937, p. 754). It was kindly supplied by Dr M. W. Parke from her stock, intended for the culture of diatoms and flagellates.

Sands were always tested in Pyrex crystallizing dishes by the free-choice method (Wilson, I953 $a$, p. 4I5) and sometimes also by conical-vessel tests (Wilson, I952, p. 66). The former method distinguishes between attractive and neutral sands, the latter between repellent and neutral sands (Wilson, I $953 b$, p. 2IO). Very many tests were made, and when time did not allow of the settled larvae being counted the comparative sizes of the settlements were 
recorded in words. The scale of words used to express number is the same as before, but for convenience it is reprinted here below Table I. All the unmetamorphosed larvae recorded were sticking to sand grains; this is a slight departure from previous practice when larvae seen to swim out of a sand sample were also counted.

Experiments are no longer described in the order in which they were made; the former method of numbering has therefore been discontinued. In this paper all experiments of the same type are grouped under one heading. The results were too numerous for all to be recorded in detail; typical results are given in the tables; others are described in the text. A few inconclusive tests are not mentioned; these did not in any way conflict with past or present findings.

Sands referred to as having been 'soaked', were kept for the period stated in sea water (or other medium) in covered Pyrex crystallizing dishes on a window bench shielded from the sun.

Each experiment was controlled with a small dish, the bottom of which was completely covered with fresh Bullhill Bank sand. This dish is not usually mentioned in the account of an experiment, or shown in the tables, but it was always employed to check the ability of the larvae to metamorphose during the actual period of the experiment. In these control dishes almost every larva was fully metamorphosed after 2 days.

In every free-choice dish, no matter what sands were tested, there were always at the end of the experiment many unmetamorphosed larvae swimming freely, or attached lightly to the surface film. Generally there were also a few sticking lightly to the glass bottom of the dish between the sand heaps. Occasionally one or two metamorphosing or metamorphosed worms were also to be seen on the glass; it was always practically certain that they had crawled out of a sand heap.

\section{THE EXPERIMENTS}

\section{Experiments with Filter-Paper}

In a preceding paper (Wilson, I953 $b$ ) it was mentioned (p. 200) that 'some tests based on filtering water in which fresh sands had been shaken gave promising, though imperfect results'. These tests had been included in experiments, carried out in late July 1952, which had been spoilt by the condition of the larvae. The results, so far as they had gone, suggested that whereas acid-cleaned Bullhill Bank sand is made attractive by soaking for some days in sea water in which fresh Bullhill Bank sand had been shaken, it is made even more attractive if the water, after the shaking, is filtered through Whatman No. 42 filter-paper (a fine-textured double acid-washed paper). This surprising result merited further investigation.

Some fresh Bullhill Bank sand, collected (II June I953) from the surface of the bank at a place where adult Ophelia worms were numerous, was 
vigorously shaken (I2 June I953) in sea water. After the grains had settled the water was poured off (for convenience such water will in what follows, and in the tables, be referred to as 'B.B. water'), a portion being filtered through a piece of Whatman No. 42 filter-paper. Small quantities of acid-cleaned Bullhill Bank sand were placed in both the filtered and the unfiltered 'B.B. water', and were also placed on the piece of paper used for the filtration. Further quantities were placed on an unused sheet of the paper in sea water, and, for control, in a dish of sea water alone. Portions of these sands were tested with 5-day-old larvae after so soaking for 5 days and some of them again after 26 days. The tests after 5 days were further controlled with acid-cleaned sand straight from storage in distilled water, and the 5-day tests included both dish and conical vessel experiments, those after 26 days dish experiments only.

The results are shown in Table I. They do not confirm the result of last year's imperfect experiment. The acid-cleaned sand which had soaked in unfiltered 'B.B. water' had become definitely more attractive (especially after 26 days) than that soaked in sea water only, but that which had been in the filtered 'B.B. water' seemed to be even slightly less favourable than that from sea water alone. The acid-cleaned sand on the filter-paper through which the 'B.B. water' had been passed seemed to be unaffected (after 5 days), but that on the unused piece of filter-paper had become markedly attractive, inducing heavy settlements in both dish and conical vessel experiments. This result being the reverse of what had been expected it may be as well to note that there is no possibility of the two papers, or the sands from them, having been interchanged or confused during the experiment. It should be noted, however, that the paper used for the filtration of the 'B.B. water' unfolded itself when placed in a dish of water and much of the sand sprinkled over it may not have been on that part of the paper which had picked up most of the particles from the water filtered through it.

At the time of the second test, after 26 days, the acid-cleaned sands from both filtered and unfiltered 'B.B. waters' had minute growths, apparently algal, on the grains and contained some ciliates. These were most numerous in the sand from the unfiltered water, and this sand was, in addition, a little silty. The control sand, from sea water only, appeared clean. These observations were made with a dissecting binocular at a magnification not exceeding $\times$ Ioo.

Some further experiments were made with filtered (No. 42 paper) and unfiltered 'B.B. water', and with the intention of obtaining improved results culture medium was added to equal quantities of the 'B.B. water' and this was controlled by diluting other portions of the 'B.B. water' with equal amounts of sea water, as well as using normal sea-water controls. The results of these more elaborate experiments were less definite than the one just described. The culture medium itself had little or no effect on the acid-cleaned sands soaked in it, neither did it appear to increase the potency of the 'B.B. 
water' to which it was added. Dilution of the 'B.B. water' may have decreased its powers of making the acid-cleaned sand attractive, at least for the relatively short periods (not exceeding I6 days) the sand was soaked in it. The results, while not showing very marked differences between the variously soaked sands, are in general agreement with those of the earlier experiment. So far as they go they do indicate that acid-cleaned sand is made attractive by soaking in unfiltered 'B.B. water', but is little affected if the 'B.B. water' first be filtered through No. 42 paper.

The unexpected result in the first experiment (Table I) where an acidcleaned sand became attractive by contact, in sea water, with unused Whatman No. 42 filter-paper led to a series of experiments to investigate the possibility that the filter-paper contained some substance which became adsorbed on the grains or which encouraged bacterial or other growths attractive to the larvae.

It is not proposed to consider all these experiments in detail. Some of them were negative, but the majority were slightly in favour of the filter-paper having some such favourable influence. The best result was obtained by soaking acid-cleaned sand in the first small quantity of sea water passed through a new piece of paper, especially (Table II) after soaking for several days. After much sea water had been passed through the paper the last quantity of water collected did not have as marked an effect. Never again was a really good settlement obtained with acid-cleaned sand allowed to lie on, or between, unused filter-papers in sea water. Indefinite results were obtained with concentrated extracts of several filter-papers, and with filter-papers washed in strong hydrochloric acid followed by distilled water. All the papers came from the same box and care was taken to avoid contamination during handling. The results are quite inconclusive and are of value only in indicating that results obtained with acid-cleaned sands soaked in filtered 'B.B. water' will either not be influenced at all, or if they are they will be in the direction of attractiveness. Thus the results with filtered 'B.B. water' already discussed can at least be accepted provisionally. It may be too, that the explanation of last year's imperfect experiment, which led to this investigation, can be explained by the favourable action of the particular piece of filter-paper then used.

\section{An Experiment with Sea Water in which Fresh Sand from the Salthouse Lake was Shaken}

From one of last year's experiments (Wilson, I953b, Expt. 57 B) it appeared that sea water in which fresh sand from the Salthouse Lake (Station II) was shaken was capable, like 'B.B. water' of making attractive an acid-cleaned sand soaked in it. To check this result a similar experiment was made this year. After washing away, with sea water, all the easily removable silt a quantity of surface sand from the Salthouse Lake (Station II) was, the day after collection, vigorously shaken in sea water. After settlement of the grains 
the sea water, now rather dirty, was poured off. It was divided into two portions, to one an equal volume of clean sea water was added, to the other an equal volume of culture medium. To these and to controls, consisting of sea water only and sea water plus an equal volume of culture medium, acid-cleaned sand from storage in distilled water was added. The sand was soaked for 7 days and then tested with 5-day-old larvae, in a free-choice dish and in conical vessels. After 2 days the results were not very definite (see Table III) but it was noted that the larvae used in this experiment swam unusually strongly, keeping mainly to the surface of the water. It was therefore decided to continue the experiment for another 3 days, and the sands from the free-choice dish were carefully put back again and some more larvae from the original culture (now 7 days old) were added. The conical vessel tests were not repeated. After a further 3 days in the dark the free-choice dish sands were again examined, with the result shown in Table III. There seems no doubt that the acidcleaned sand had been improved by soaking in the 'S.L. water' and that the addition of culture medium, as had been found in several other experiments, has little or no effect on acid-cleaned sands soaked in it.

\section{Acid-cleaned Sands Soaked in Sea Water in the Presence of Fresh Natural Sands}

The experiences with 'B.B. water' and 'S.L. water' led to another type of experiment in which an acid-cleaned sand was placed at one side of a dish with freshly collected Bullhill Bank or Salthouse Lake sand at the other. Such acid-cleaned sands when tested after only a few days showed no difference from the controls kept in sea water only, but after several weeks they markedly improved in attractiveness, but then so too did the controls, though usually not to quite the same extent. A series of tests is recorded in Table IV from which it appears that the fresh Salthouse Lake sand had an even more favourable influence on the acid-cleaned sand kept with it than had Bullhill Bank sand itself. This, however, was not so in the experiment recorded in Table V. It is unfortunate that the experiment being lengthier than originally anticipated the control acid-cleaned sand kept in sea water had all been used up before the last tests were made.

In another series of tests (see Table V) the fresh sands occupied most of the bottom of the dish, the acid-cleaned sand being placed in cleared areas in the middle. The cleaned sands were thus completely surrounded by the fresh sands. A mixture of equal parts of sea water and culture medium was used instead of sea water only. Fresh sand for a depth of I2-I8 in. on the Bullhill Bank was tried as well as sand from the surface. The Salthouse Lake sand was, as usual, from the surface layer. The results, while not very definite, point to a slight improvement of the acid-cleaned sand surrounded by the fresh Bullhill Bank surface sand and little or no improvement by the deep sand or by the sand from the Salthouse Lake. It is possible that the soaking times were too 
short for definite results. Moreover, the larvae used on 2 August 1953 (and this applies also to the previous experiment) were noticeably less ready to settle than usual for their age. This is deduced from their tendency to swim vigorously up against the surface film and from their behaviour in control dishes (not recorded in the tables) plentifully strewn with fresh Bullhill Bank sand. As has been pointed out before (Wilson, I953 b, p. 22I), it is usual for some cultures of larvae to show less readiness to metamorphose than others of the same age.

\section{Acid-cleaned Sands Soaked in Sea Water, in Distilled Water and in Culture Medium}

Towards the end of the 1953 series of experiments it was found that acidcleaned sands which had been soaked in sea water as controls for earlier experiments had become markedly attractive to the larvae. An acid-cleaned sand soaked for a few days in sea water had often induced a few more larvae to settle in it than had the same sand stored in distilled water and tested with it in the same free-choice dish. However, the increase in attractiveness had almost always been very small. With acid-cleaned sands in sea water for a varying number of days (from I to 26) there were only two occasions out of twenty-three when 5-day-old larvae settled in appreciable numbers (several metamorphosed and several metamorphosing) and on those two occasions (one after 5 days of soaking and one after Io) there were no tests of sands from distilled water storage with which to compare. It is possible that the larvae used in those particular experiments were more ready to settle than usual.

There were three tests with 6-day-old larvae with sands soaked for 20,22 (see Table VII) and 25 days, and these all gave good settlements, but no comparative tests with acid-cleaned sands from distilled water were made. It must be remembered that 6-day-old larvae usually settle more readily than do 5-day-old.

Of three tests with acid-cleaned sand soaked for 37,40 and 43 days, respectively, all induced good to heavy settlements while there were only light settlements in sand from distilled water storage tested with them. Of these three results one is recorded in Table IV (virtually with 6-day-old larvae), the other two in Table VI which shows the results of four tests of an acid-cleaned sand kept in sea water over a period of nearly 6 weeks. In the last test, on 25 July 1953, the larvae were in the free-choice dish for 3 days instead of the usual 2 .

It will be realized that the experiments were not planned as they are here presented. This explains the lack of uniformity with regard to the age of the larvae used for testing and the occasional absence of control sands from distilled water. It was not until late in the season that there was any suspicion that soaking acid-cleaned sands in sea water for long periods improved them, 
and it was then too late to arrange further experiments. None the less, from the data just given, it seems impossible to avoid the conclusion that soaking in sea water has this favourable effect.

Reference has frequently been made to using acid-cleaned sand stored in distilled water as a control. During the course of the 1953 experiments such sand was tested sixteen times in free-choice dishes. Only on one occasion (recorded in Table VI) was there even a moderate settlement; in all other instances there was either no settlement or a very small one. Acid-cleaned Bullhill Bank sand stored for over a year in distilled water was tested with 6-day-old larvae in a free-choice dish with sand stored for 50 days only. In neither, after 2 days, were any metamorphosed worms to be found, and only a few or very few metamorphosing ones, and about the same number unmetamorphosed. Thus acid-cleaned sand kept in distilled water does not increase in attractiveness, as it does when kept in sea water.

In several experiments culture medium was added to the sea water in which acid-cleaned sand was soaking, with the intention of encouraging the growth of autotrophic organisms already present in fresh sands. The effect of culture medium added to sea water only had therefore to be determined. In Tables III, $\mathrm{V}$ and VII comparisons between sands from sea water only and from sea water to which culture medium was added have already been given, and there were a number of others. Of eleven distinct tests there was no difference in four; in the remaining seven the sand from the culture medium was either slightly more attractive (three tests) or slightly more repellent (four tests, the most positive in the repellent direction being recorded in Table VII) than sand from sea water only. It may thus be concluded that for the relatively short periods of soaking employed (not more than 22 days) the addition of culture medium to plain sea water has no appreciable effect.

\section{Experiments with Diatom and Flagellate Cultures}

The possibility that the attractiveness of Bullhill Bank natural sand is due, partly at least, to the presence on the grains of living micro-organisms led to experiments in which acid-cleaned sand was kept for 2-3 weeks with living diatoms and flagellates. A mixture of several species of each (kindly provided by $\operatorname{Dr}$ M. W. Parke from the stock cultures kept at the Laboratory) was used for the first experiment, the results of which are recorded in Table VII. Complete counts were made of the larvae settled in the two controls (tests I and 2), but time did not allow of a complete count of the much larger number of larvae settled in the sand with the diatoms and flagellates (test 3), and after as many as possible had been removed and counted it was obvious that at least as many again were left in the sand. It should be noted that the sand was rinsed in plain sea water before testing and many diatoms and flagellates were then washed away. The sand grains were thus left relatively clean, but numbers of minute diatoms and flagellates could be seen on the grains while the count 
of larvae was being made. Conical vessel tests (not shown in the table) of the same sands, run concurrently, gave fairly heavy and very similar settlements for all three sands, from which it should probably be inferred that the increased attractiveness of the sand from the diatom and flagellate culture was actually only slight. This seems to be confirmed by a later experiment (Table VIII) in which mixed diatoms and mixed flagellates were used separately as well as together. It was only in the sands which had been in the presence of flagellates that any noticeable increase in settlement was obtained and even here none had fully metamorphosed after 3 days in the free-choice dish (no conical vessel tests were made). In this experiment numerous flagellates were stuck to the sand grains but the diatoms seem to have been lost from the sand during the rinse in sea water immediately before testing.

Taking the two experiments together it seems reasonable to conclude that the presence on the acid-cleaned grains of flagellates, or possibly bacteria from their particular cultures, has some slight attraction for the larvae.

An attempt was made to culture organisms from fresh Bullhill Bank sand and transfer these to acid-cleaned sands. Diatoms and some other organisms multiplied in culture medium but the acid-cleaned sand kept with them was only slightly improved after I5 days. The grains were covered with adherent diatoms, singly and in clusters, in a manner not seen in fresh Bullhill Bank sand. There may have been too many of them.

\section{Experiments with Organic Extracts}

An experiment with acid-cleaned sand kept for half an hour in an extract of Ulva, and for the same period in starch dextrine gave almost negative results. The Ulva extract had no effect, but the sand with the starch was apparently slightly improved compared with the same sand from distilled water. However, a later test with sand kept in starch dextrine for $28 \mathrm{~h}$ was completely negative.

\section{Acid-cleaned Sand kept with Adult Ophelia bicornis}

In a previous experiment (Wilson, I953 $a$, Expt. 5I) some washed Salthouse Lake sand kept with adult Ophelia worms for several days had been made even less attractive than before. It was considered desirable to repeat this experiment with acid-cleaned Bullhill Bank sand. Accordingly, a few spent worms were kept in a clean dish for 2 or 3 days until they had emptied their guts of all sand grains. They were then transferred to another dish with a fair quantity of acid-cleaned Bullhill Bank sand. It was noticeable that they would not burrow into this sand (as they normally do into fresh sand), but lay on the top. After 4 days a little of this sand was tested, both by free-choice dish and conical vessel tests, against sand from sea water only. It was found to attract slightly fewer larvae than the latter, but in both the settlements were small. 
A similar result was obtained with more of the same sand after I6 days with the adult Ophelia worms. The presence of the adult worms had not improved the sand, neither had they markedly worsened it.

\section{Tests for Gregarious Settlement}

It has been shown that the larvae of the oyster (Cole \& Knight-Jones, I949), of the acorn barnacle Elminius modestus (Knight-Jones \& Stephenson, I950) and of the polychaete Spirorbis borealis (Knight-Jones, I95I) when ready to settle are attracted by the presence of newly metamorphosed young of their own species. There was therefore a distinct possibility that the larvae of Ophelia bicornis might show a preference for settling in sand in which others of their kind were metamorphosing or had recently metamorphosed. In order to test for this two experiments were arranged in which 5-day-old larvae were given a choice between acid-cleaned sand containing metamorphosing and recently metamorphosed larvae from an earlier fertilization and similar sand without. In order to distinguish the younger larvae from the older the former were lightly stained with methylene blue. The ability of the stained larvae to metamorphose was concurrently tested in another dish containing fresh Bullhill Bank sand, in this they settled and metamorphosed normally and as readily as did larvae from the same fertilization not stained and separately tested.

The result of the first of these experiments is given in Table IX from which it will be seen that unfortunately three of the unstained older and recently metamorphosed young worms had during the course of the experiment crawled into the pile of sand which was not supposed to contain them. There were, of course, very many more of these young worms in the other pile, the sand of which was spread by their activities until it occupied a greater area than it had done originally. On the clean glass bottom of the dish, particularly in the neighbourhood of this pile, were a number of metamorphosing and metamorphosed larvae, both stained and unstained, which had apparently crawled out of the sand. These were not counted, and the figures given for this pile in the Table are therefore lower than they should be, but only by a small fraction of the total possible. A curious feature of the figures for the stained younger larvae is that almost all found in the sand (there were many still swimming freely in the dish or lightly attached to the surface film of the water) were fully metamorphosed. This is unusual for this type of dish experiment, where newcomers normally settle in an attractive sand at any time throughout the duration. It seems that here settlement must have taken place mainly during the first or second day and very little afterwards, and it is not clear why this should be. The number settled in the sand is higher than what would normally be expected in a neutral acid-cleaned sand, but there is no significant difference between the pile with the three older unstained worms and the pile with the II4. Of course, if any stimulating soluble substance is given 
off during metamorphosis, or for a short while afterwards, it would quickly diffuse throughout the dish and affect both sands alike. That this hypothetical substance, the actual existence of which is doubtful, did not of itself, without the presence of sand, bring about metamorphosis is obvious from the large number of younger stained larvae still swimming freely in the dish, or attached singly or in clusters, unmetamorphosed, to the surface film. The correct interpretation of these results is thus not clear, but they do not seem to offer much support for the existence of gregarious settlement in this species.

The second and later experiment, the results of which are recorded in Table $\mathrm{X}$, are in general agreement with the conclusion from the earlier one. Conducted on similar lines, with 5-day-old larvae stained before use, it differed only in using acid-cleaned sand from distilled water as the control and fewer settling older and unstained larvae in the test sand. Some of these unstained larvae must have migrated to the control sand early in the experiment and quite a number were found, unmetamorphosed, on the surface film with stained larvae when the dish was examined immediately after removal from the dark box in which it had been kept for 3 days. A fair number of metamorphosed young worms, unstained, and one or two stained were crawling on the glass bottom of the dish, especially around both piles of sand. In comparison with the first experiment it is noticeable that only a small number of stained larvae settled in either pile.

\section{Experiments with an Almost Pure Charcoal}

In many previous experiments forms of activated charcoal have produced heavy settlements, but it has never been quite certain whether it was the carbon which attracted the larvae or some impurity such as copper (Wilson, I953 b, p. 224). I am indebted to Mr F. A. J. Armstrong for making from 'AnalaR' sucrose a charcoal almost totally free from impurity (analysis for copper, by F.A.J.A. gave less than 0.2 parts/million). That this charcoal had some absorptive properties was demonstrated by its power to decolorize weak dye solutions. The sucrose charcoal was, for testing, mixed with an acidcleaned sand; the results are recorded in Table XI (two separate tests with different batches of larvae). The larvae were undoubtedly strongly attracted by it, and if the numbers settling seem fewer than in some earlier experiments with other forms of charcoal this is to be explained by failure to obtain an intimate mixture of the sucrose charcoal with the sand. This charcoal was much coarser than that manufactured for decolorizing purposes, so often used previously, and did not adhere to the grains at all. The particles were angular and the mixtures contained much more sand than charcoal.

From these results it is probably permissible to conclude that the carbon of the charcoal rather than the impurities attracts the larvae, but whether for its absorptive property or for some other reason is still unknown. 


\section{Other Experiments}

The possibility that the minute amount of copper contained in activated charcoal might stimulate the larvae to metamorphose (Wilson, I953 b, p. 224) led to an experiment in which acid-cleaned sand was soaked for an hour in ioo $\mu \mathrm{g} \mathrm{Cu} / 100 \mathrm{ml}$. sea water. The sand was then well washed in filtered sea water and tested in a free-choice dish with similar sand not so soaked as a control. After 2 days the control sand contained one or two metamorphosing larvae and two or three unmetamorphosed ones, while the sand from the copper solution contained only a large number of unmetamorphosed larvae, many of them dead. A likely explanation is that larvae exploring the sand were quickly weakened by the copper and, unable to swim away, were eventually killed by it.

The I952 experiments (Wilson, I953b) included several tests in which neutral sands (contained in bolting-silk envelopes) buried in fresh sands acquired an attractive factor from fresh Bullhill Bank sand but not from fresh Salthouse Lake (Station II) sand. It has also been shown that heating Bullhill Bank sand in water to about $100^{\circ} \mathrm{C}$ (previously referred to as 'normal sterilization') destroys the attractive factor, but no check had been made in which a neutral sand, inside a bolting-silk envelope, had been buried in sand so heated. Thus among the present experiments were included tests of an acidcleaned sand, contained within bolting-silk envelopes, buried in heated Bullhill Bank sand and in heated Salthouse Lake (Station II) sand, in sea water for 8 days. The buried sands were then presented to larvae in a free-choice dish and in conical vessels, using as control a similar sand kept for 8 days in sea water only. The sand exposed to the heated Bullhill Bank sand induced light settlements almost identical with those in the control, but that exposed to the heated Salthouse Lake sand induced smaller settlements, suggesting that it had become a little repellent.

\section{Discussion}

There have been few methods by which a neutral sand has been transformed into an attractive one. They have included the use of charcoal, a substance unlikely to be present in the Exe sandbanks, and extracts of filter-paper which gave the curious results already discussed. Almost the only other methods have all employed some form of soaking the neutral sand in sea water under conditions likely to encourage growths of micro-organisms too small to be readily visible during normal examination of the sands. It will therefore be well to consider what evidence there is from these experiments that such organic growths do indeed form on clean sand grains, immersed in sea water, and what evidence that the larvae react to their presence.

The first fact to note is that acid-cleaned sand stored in distilled water, in stoppered bottles, even for over a year, does not increase in attractiveness. 
Distilled water, devoid of nutrients, does not encourage growths. On the other hand, it is improbable that anything kept in even Berkefeld-filtered sea water, contained in a perfectly clean dish covered only by a loose glass plate, could remain for long free from bacteria, etc. Such sea water must almost always contain some nutrient material sufficient for small growths to take place: After several weeks small organisms, motile and non-motile, have always been seen in such dishes, and a scratch on the bottom with a needle has generally revealed a very thin film of slime.

I am indebted to Dr C. H. Jellard (Public Health Laboratory Service) for endeavouring to demonstrate, by normal bacteriological techniques, that acidcleaned sand does become coated by bacteria, etc., after days or weeks in filtered sea water. Unfortunately the irregularities, natural scratches, colourings and other markings on the sand grains made this an almost impossible task. In substitution for the sand grains we immersed acid-cleaned cover glasses in Berkefeld-filtered sea water for various periods, and it was then easy to see that they indeed became covered by bacteria and other organisms and that these increased in abundance for a time, never becoming excessively numerous. The control cover-glasses, kept in distilled water in stoppered bottles, remained clean, as was expected.

That the organisms which develop in dishes of filtered sea water are not always the same species is apparent when such dishes are compared after several weeks. Some will then contain minute diatoms not present in others, or rounded unidentified objects or flocculent growths absent from other dishes on the same bench close by. Occasionally minute ciliates or flagellates are seen. Acid-cleaned sand kept in these dishes for several weeks or even months looks clean until close inspection reveals that there are on the grains small numbers of the organisms which are to be seen more easily on the glass of the dish. It is likely that some species are more acceptable to the larvae than are others. This is to some extent indicated by the experiments with diatoms and flagellates from culture; the flagellates (or unseen organisms introduced with them) having some slight attraction for the larvae, the diatoms seemingly none at all, even diatoms cultured from Bullhill Bank itself. Differences in the kinds of organisms growing on the acid-cleaned sands after days or weeks in sea water could explain some of the small variations in intensity of settlement in sands from different dishes, or in sand from the same dish tested at different times. But on the whole it remains true that, within the period of time covered by the 1953 experiments, the longer the acid-cleaned sands were soaked in sea water, the more they increased in attractiveness.

The fact that acid-cleaned sand soaked in sea water in which fresh Bullhill Bank or Salthouse Lake sands had been shaken becomes more attractive than the same sand kept for an equal time in sea water only is very suggestive of living organisms. It may be assumed that many organisms are washed off the natural sands by the shaking and subsequently adhere to and grow on the 
acid-cleaned grains. ${ }^{1}$ Moreover, these are likely to be the species that are the natural food of the young worms. Even the presence of the fresh sands in the dish with the acid-cleaned sand eventually imparts to the latter a little more attractiveness than soaking for a like period in sea water alone. The addition, in the I952 experiments (Wilson, I953 b), of a few grains of fresh sand, from either the Bullhill Bank or the Salthouse Lake, imparted a degree of attractiveness to acid-cleaned sands, but more markedly so after several days at room temperature during which organisms introduced on the fresh grains would have had time to multiply and spread. This happened both in the light and in the dark, and although other explanations are possible this suggestion that living organisms, multiplied after a lapse of time, were responsible for the increased attractiveness is at least reasonable. Some similar inoculation experiments, in 1952, using weak media instead of sea water only, and at a raised temperature in a warm dark oven, had similar though less definite results.

The burying of a neutral sand, enclosed within a bolting-silk envelope, in fresh Bullhill Bank sand has been shown to be a sure way of making that sand attractive (Wilson, I953 b). But if the Bullhill Bank sand is first heated to about $100^{\circ} \mathrm{C}$ in water no such increase of attractiveness is apparent. This again can be explained on the assumption that in the first instance living organisms pass through the bolting silk to mingle with the neutral sand, as indeed they were observed to have done, whereas in the second instance there would be no living organisms in the sand after heating. In all earlier experiments treatments of fresh Bullhill Bank sand which would have killed organisms living in it have always reduced its attractiveness to Ophelia larvae (for a summary of these treatments see Wilson, I953a, pp. 423-4).

Occasionally, after treating a neutral sand by one or other of the methods by which micro-organisms would be encouraged to grow on it the sand has induced a settlement about half as large as that obtained in fresh Bullhill Bank sand, presented to the larvae under the same conditions. This is a decided advance on anything achieved during earlier breeding seasons when almost the only known method of ensuring, especially under free-choice conditions, a heavy settlement in sands other than fresh Bullhill Bank sand was to use activated charcoal, the attractiveness of which for the larvae is still unexplained.

The solution of the main problem, that of explaining how O. bicornis larvae recognize their own natural sand, now seems to be within reach. From the results of previous work it can be accepted that suitable grade is one of the factors influencing the larvae in their choice of a sand in which to settle. Cleanliness is another. But this cleanliness is only relative, for a sand of

\footnotetext{
${ }^{1}$ Filtration of the 'B.B. water' through No. 42 filter-paper generally reduced its efficiency in making attractive acid-cleaned sand soaked in it (see pp. 363-4) but in view of the inconsistent effects of filter-paper these results are not advanced in support of the present thesis.
} 
suitable grade, if perfectly free from all organic matter, is neutral in the sense of neither encouraging nor discouraging larvae to settle. Only when the relatively clean grains carry living micro-organisms, or their organic products, are they really attractive to larvae in the exploratory phase prior to settlement. It seems most likely that these micro-organisms must belong to a limited, though perhaps fairly extensive range of types and species, and that there is an optimum abundance just as there seems to be an optimum size range of sand grains. If the two optima coincide then there will be produced the best possible conditions for settlement.

An explanation such as that just outlined would bring O. bicornis larvae more or less into line with the larvae of some sedentary animals which do not settle on solid surfaces until after the surfaces have become coated with bacteria or other organisms or with the slime films produced by them (for references and a short discussion see Wilson, I952, pp. 52-3), although these are probably not sought for as food. It would also fit the many facts now known concerning the settlement reactions of Ophelia larvae.

Attraction is, however, only half the picture. During I953 no attention was paid to a repellent factor which seems to co-exist with an attractive one on the Salthouse Lake sands in which adult Ophelia does not live. It has previously been suggested that the larvae may dislike some kinds of dead organic matter on the sand grains, or the presence of too many micro-organisms, or the wrong kinds. It is probable that variations in the quantity and quality of the organic matter, living or dead, on and among the sand induces corresponding variations in the intensity of the settlement of Ophelia larvae coming into contact with them.

\section{SUMMARY}

During the 1953 breeding season attention was paid to ways in which neutral acid-cleaned sand may be made attractive to the larvae of Ophelia bicornis. It was found that one of the most effective methods is to soak the sand for a long period in sea water, during which time there is evidence that the grains acquire a coating of living micro-organisms. Similar soaking in water in which fresh sands have been shaken, or in the presence of fresh sands in the same dish, are even more effective ways of rendering the neutral sand attractive. It is concluded that the presence on the grains of living micro-organisms, or products of their activity, in not too great an abundance, makes the grains attractive to the larvae.

Acid-cleaned sand soaked for long periods in distilled water is not made attractive to the larvae, neither does it acquire a coating of micro-organisms. This was demonstrated by substituting acid-cleaned cover-glasses for sand, and comparing the results of keeping them in distilled water and in sea water.

An acid-cleaned sand enclosed within a bolting-silk envelope and buried, in sea water, in Bullhill Bank sand, previously heated to about $100^{\circ} \mathrm{C}$, does 
not become attractive, as it does when the Bullhill Bank sand is fresh and unheated. The difference is regarded as being due to the absence of living organisms in the pre-heated sand.

Diatoms alone are ineffective in making a neutral sand attractive to the larvae, but the presence of flagellates appears to impart some slight attraction.

The addition of culture medium (Erdschreiber) to the sea water in which the sands are soaked is without significant effect. This type of culture medium may not be a suitable nutrient fluid for the kinds of organisms the larvae like.

It is shown that a very pure form of charcoal, made from sucrose, is as effective in inducing larvae to settle as were impure forms in earlier experiments. It is concluded that it is the carbon itself, and not contained impurities, which is attractive, although why this should be is still an unsolved problem.

It was found that acid-cleaned sand is sometimes made attractive by contact in sea water with Whatman No. 42 filter-paper, or in extracts from it. The results are, however, erratic and their significance obscure.

\section{REFERENCES}

Cole, H. A. \& KNIGHT-Jones, E. W., I949. The settling behaviour of larvae of the European flat oyster Ostrea edulis L., and its influence on methods of cultivation and spat collection. Fish. Invest., Lond., Ser. 2, Vol. I7, No. 3, pp. I-39.

Gross, F., I937. Notes on the culture of some marine plankton organisms. F. Mar. biol. Ass. U.K., Vol. 21, pp. 753-68.

KNIGHT-JoNES, E. W., I95I. Gregariousness and some other aspects of the setting behaviour of Spirorbis. F. Mar. biol. Ass. U.K., Vol. 30, pp. $20 \mathrm{I}-22$.

Knight-Jones, E. W. \& Stephenson, J. P., I950. Gregariousness during settlement in the barnacle Elminius modestus Darwin. F. Mar. biol. Ass. U.K., Vol. 29, pp. 28I-97.

WILson, D. P., I952. The influence of the nature of the substratum on the metamorphosis of the larvae of marine animals, especially the larvae of Ophelia bicornis Savigny. Ann. Inst. océanogr. Monaco, T. 27, pp. 49-1 56.

- I953a. The settlement of Ophelia bicornis Savigny larvae. The I95I experiments. F. Mar. biol. Ass. U.K., Vol. 31, pp. 413-38.

- I $953 b$. The settlement of Ophelia bicornis Savigny larvae. The 1952 experiments. F. Mar. biol. Ass. U.K., Vol. 32, pp. 209-33. 


\section{TABLE I}

Acid-cleaned Bullhill Bank sand soaked in

Tests Days of beginning soaking

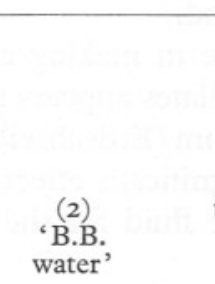

\begin{tabular}{|c|c|c|c|}
\hline & (4) & & \\
\hline & $\begin{array}{c}\text { Sea } \\
\text { water }\end{array}$ & (5) & \\
\hline (3) & on & Sea & \\
\hline & $\begin{array}{l}\text { filter- } \\
\text { paper }\end{array}$ & $\begin{array}{c}\text { water } \\
\text { on }\end{array}$ & \\
\hline through & used & unused & (6) \\
\hline $\begin{array}{l}\text { filter- } \\
\text { paper }\end{array}$ & $\begin{array}{l}\text { for } \\
\text { no. } 3\end{array}$ & $\begin{array}{l}\text { filter- } \\
\text { paper }\end{array}$ & $\begin{array}{l}\text { Distilled } \\
\text { water }\end{array}$ \\
\hline
\end{tabular}

Metd
Meting
Unmet.

\section{(I)}

water

2
3
7

Settlements after 2 days in free-choice dish

I7. vi. $53 \quad 5 \quad \begin{aligned} & \text { Metd } \\ & \text { Meting } \\ & \text { Unmet. }\end{aligned}$

3
4
12

I
3
I

None
I
7

35
I6
I2

Settlements after 2 days in conical vessels

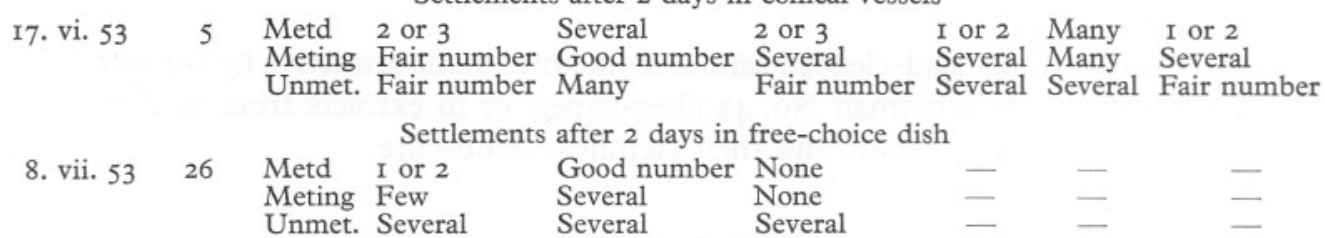

Metd =metamorphosed; meting =metamorphosing; unmet. = unmetamorphosed. 'B.B. water'-see text, p. 363 .

Scale of words used to express number in Tables I-XI:

$\begin{array}{ll}\text { Very few (sometimes also expressed in numbers I-4) } & \text { Good number } \\ \text { Few } & \text { Many } \\ \text { Several } & \text { Very many } \\ \text { Fair number } & \text { Multitude }\end{array}$

\section{TABLE II}

Set A. Acid-cleaned Bullhill Bank sand soaked for $2 \mathrm{~h}$ in

\begin{tabular}{|c|c|c|c|c|c|}
\hline & $\begin{array}{c}\text { (I) } \\
\text { Sea } \\
\text { water }\end{array}$ & $\begin{array}{l}\text { (2) } \\
\text { Sea water } \\
\text { and } \\
\text { between } 2 \\
\text { pieces of } \\
\text { filter- } \\
\text { paper }\end{array}$ & $\begin{array}{c}\text { (3) } \\
\text { Sea water } \\
\text { and } \\
\text { between } 2 \\
\text { pieces of } \\
\text { filter-paper } \\
\text { previously } \\
\text { washed with } \\
\mathrm{HCl}\end{array}$ & $\begin{array}{l}\text { (4) } \\
\text { First small } \\
\text { volume of sea } \\
\text { water passed } \\
\text { through one } \\
\text { filter-paper }\end{array}$ & $\begin{array}{l}\text { (5) } \\
\text { Small volume of } \\
\text { sea water passed } \\
\text { through the filter } \\
\text { paper used for }(4 \\
\text { after previous } \\
\text { passage of much } \\
\text { sea water }\end{array}$ \\
\hline Metd & None & None & None & None & None \\
\hline Meting & Several & Severa & Sev & & eral \\
\hline \multirow[t]{2}{*}{ Unmet. } & Several & Several & Several & Fair number & Several \\
\hline & & cid-cl & & & above \\
\hline L & Several & Few & Several & Many & Fair $\mathrm{n}$ \\
\hline Meting & Several & Several & Fair & & Fair num \\
\hline Unmet. & Several & Several & Several & Fair number & Several \\
\hline
\end{tabular}

The larvae used for both sets were from the same culture and were 5 days old. A single free-choice dish was used for testing each set and the settlements were those obtained after 2 days. Different filter-papers were used for each set. 


\section{TABLE III}

Acid-cleaned Bullhill Bank sand soaked for 7 days in

\begin{tabular}{|c|c|c|c|c|}
\hline & $\begin{array}{c}\text { (I) } \\
\text { Sea water }\end{array}$ & $\begin{array}{l}\text { Sea water plus } \\
\text { an equal volume } \\
\text { of culture medium }\end{array}$ & $\begin{array}{l}\text { (3) } \\
\text { 'S.L. water' } \\
\text { plus an equal } \\
\text { volume of sea } \\
\text { water }\end{array}$ & $\begin{array}{c}\text { (4) } \\
\text { 'S.L. water' } \\
\text { plus an equal } \\
\text { volume of } \\
\text { culture medium }\end{array}$ \\
\hline \multicolumn{5}{|c|}{ Settlements after 2 days in free-choice dish } \\
\hline Metd & None & None & I & None \\
\hline Meting & None & None & $\mathrm{I}$ & None \\
\hline Unmet. & Very few & Very few & Few & Few \\
\hline \multicolumn{5}{|c|}{ Settlements after 2 days in conical vessels } \\
\hline Metd & I or 2 & None & Several & Few \\
\hline Meting & Very few & Very few & Fair number & Good number \\
\hline Unmet. & Good number & Good number & Several & Several \\
\hline
\end{tabular}

Settlements after 3 further days in free-choice dish

$\begin{array}{lllrl}\text { Metd } & 3 & 5 & 24 & 29 \\ \text { Meting } & 3 & 3 & 6 & 14 \\ \text { Unmet. } & 5 & 5 & 5 & 12\end{array}$

\section{TABLE IV}

Acid-cleaned Bullhill Bank sand soaked in

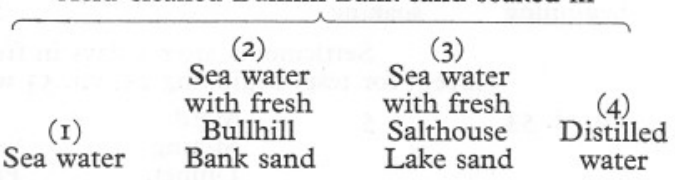

Settlements after 2 days in free-choice dish

\begin{tabular}{|c|c|c|c|c|c|c|}
\hline I7. vi. 53 & 5 & $\begin{array}{l}\text { Metd } \\
\text { Meting } \\
\text { Unmet. }\end{array}$ & $\begin{array}{c}\text { I or } 2 \\
\text { I or } 2 \\
\text { Several }\end{array}$ & $\begin{array}{l}\text { None } \\
\text { I or } 2 \\
\text { Several }\end{array}$ & $\begin{array}{l}\text { None } \\
2 \text { or } 3 \\
\text { Several }\end{array}$ & $\begin{array}{l}\text { I } \\
\text { I } \\
5\end{array}$ \\
\hline 8. vii. 53 & 26 & $\begin{array}{l}\text { Metd } \\
\text { Meting } \\
\text { Unmet. }\end{array}$ & $\begin{array}{c}\text { I or } 2 \\
\text { Few } \\
\text { Several }\end{array}$ & - & - & - \\
\hline 25. vii. 53 & 43 & $\begin{array}{l}\text { Metd } \\
\text { Meting } \\
\text { Unmet. }\end{array}$ & $\begin{array}{l}\text { Fair number } \\
\text { Very few } \\
\text { Very few }\end{array}$ & $\begin{array}{l}\text { Good number } \\
\text { Several } \\
\text { Fair number }\end{array}$ & $\begin{array}{c}\text { Many } \\
\text { Many } \\
\text { Fair number }\end{array}$ & $\begin{array}{l}\text { Very few } \\
\text { Very few } \\
\text { Very few }\end{array}$ \\
\hline 2. viii. 53 & $5 \mathrm{I}$ & $\begin{array}{l}\text { Metd } \\
\text { Meting } \\
\text { Unmet. }\end{array}$ & E & $\begin{array}{r}\text { I0 } \\
7 \\
5\end{array}$ & $\begin{array}{r}47 \\
\text { I6 } \\
8\end{array}$ & $\begin{array}{l}\text { None } \\
\text { None } \\
\text { Very few }\end{array}$ \\
\hline
\end{tabular}


$\begin{array}{cc}\text { Tests } & \text { Days of } \\ \text { beginning } & \text { soaking }\end{array}$

\section{2. vii. 539}

2. viii. $53 \quad 19$

\section{TABLE V}

Acid-cleaned Bullhill Bank sand soaked in

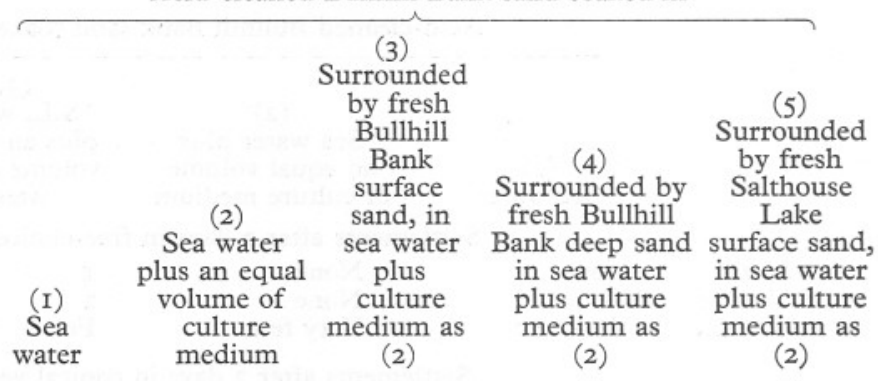

Settlements after 2 days in free-choice dish

$\begin{array}{llllll}\text { Metd } & \text { I or } 2 & \text { Few } & \text { Several } & \text { Very few } & \text { Very few } \\ \text { Meting } & \text { Few } & \text { Several } & \text { Several } & \text { Few } & \text { Several } \\ \text { Unmet. } & \text { Several } & \text { Several } & \text { Several } & \text { Fair number } & \text { Several } \\ \text { Metd } & \text { Few } & \text { I or } 2 & \text { Several } & \text { Very few } & \text { Few } \\ \text { Meting } & \text { Very few } & \text { Very few } & \text { Very few } & \text { Few } & \text { Very few } \\ \text { Unmet. } & \text { Very few } & \text { Few } & \text { Very few } & \text { Several } & \text { Few }\end{array}$

\section{TABLE VI}

Acid-cleaned Bullhill Bank sand soaked in

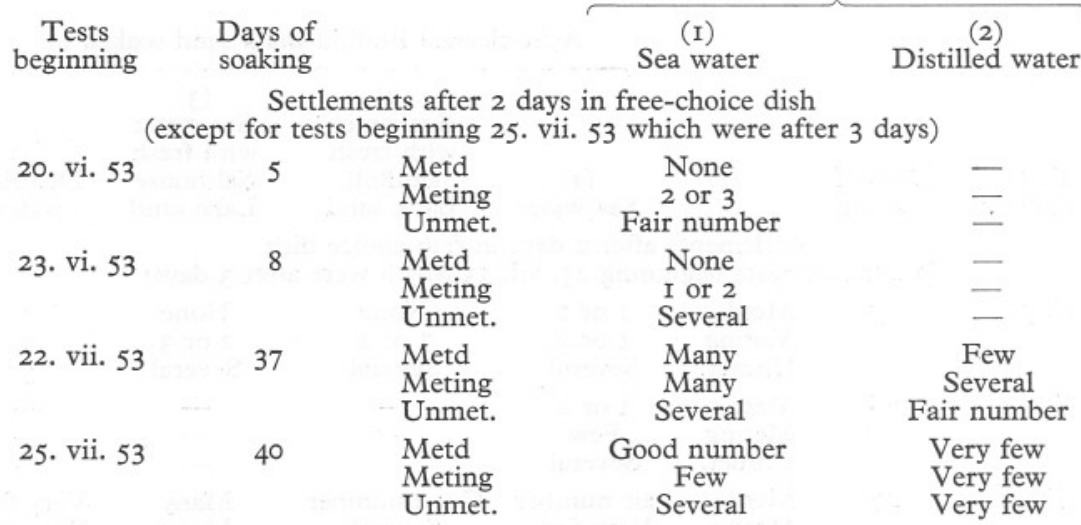

\section{TABLE VII}

Acid-cleaned Bullhill Band sand 22 days in

$\overbrace{\begin{array}{c}\text { Sea } \\ \text { water }\end{array}}^{\begin{array}{c}\text { (2) } \\ \text { Culture } \\ \text { medium }\end{array}} \begin{gathered}\begin{array}{c}\text { Culture medium } \\ \text { containing diatoms } \\ \text { and flagellates }\end{array} \\ \text { and }\end{gathered}$

Settlements obtained with 6-day-old larvae after 2 days in free-choice dish

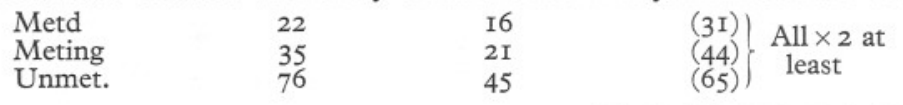




\section{TABLE VIII}

Acid-cleaned Bullhill Bank sand I5 days in

\begin{tabular}{|c|c|c|c|c|c|}
\hline & $\begin{array}{c}\text { (I) } \\
\text { Sea water }\end{array}$ & $\begin{array}{c}\text { (2) } \\
\text { Sea water } \\
\text { plus an } \\
\text { equal } \\
\text { volume } \\
\text { of culture } \\
\text { medium }\end{array}$ & $\begin{array}{l}\text { (3) } \\
\text { Medium } \\
\text { as (2) } \\
\text { containing } \\
\text { diatoms }\end{array}$ & $\begin{array}{l}\text { (4) } \\
\text { Medium as } \\
\text { (2) containing } \\
\text { flagellates }\end{array}$ & $\begin{array}{l}\text { (5) } \\
\text { Medium as } \\
\text { (2) containing } \\
\text { diatoms and } \\
\text { flagellates }\end{array}$ \\
\hline \multicolumn{6}{|c|}{ Settlements obtained with 5 -day-old larvae after 3 days in free-choice dish } \\
\hline $\begin{array}{l}\text { Metd } \\
\text { Meting } \\
\text { Unmet. }\end{array}$ & $\begin{array}{l}\text { None } \\
\text { Very few } \\
\text { Few }\end{array}$ & $\begin{array}{l}\text { None } \\
\text { Very few } \\
\text { Few }\end{array}$ & $\begin{array}{l}\text { None } \\
\text { Very few } \\
\text { Few }\end{array}$ & $\begin{array}{l}\text { None } \\
\text { Fair number } \\
\text { Many }\end{array}$ & $\begin{array}{l}\text { None } \\
\text { Fair number } \\
\text { Many }\end{array}$ \\
\hline
\end{tabular}

\section{TABLE IX}

Acid-cleaned Bullhill Bank sand 5 days in

(2)

(I)

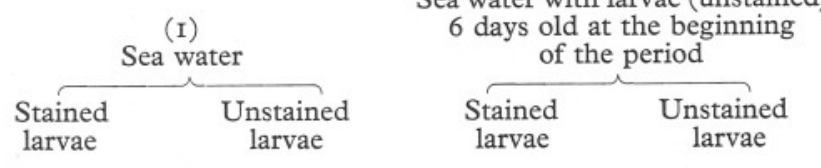

Metd
Meting
Unmet.

Settlements after 3 days in free-choice dish

$\begin{array}{rrr}23 & 3 & 28 \\ 2 & \text { None } & 2 \\ 6 & \text { None } & 10\end{array}$

II 4
I
I

\section{TABLE X}

Acid-cleaned Bullhill Bank sand

(2)

(I)

Stored in distilled water

$\overbrace{\substack{\text { Stained } \\ \text { larvae }}}^{\begin{array}{c}\text { Unstained } \\ \text { larvae }\end{array}}$

Settlements after 3 days in free-choice dish

$\begin{array}{lllll}\text { Metd } & \text { None } & \text { Very few } & \text { None } & \text { Fair number } \\ \text { Meting } & \text { Very few } & \text { Several } & \text { Very few } & \text { Several } \\ \text { Unmet. } & \text { Several } & \text { Few } & \text { Several } & \text { Few }\end{array}$

In sea water for 3 days with larvae (unstained) 5 days old at the beginning of the period

$\overbrace{\substack{\text { Stained Unstained } \\ \text { larvae }}}^{\text {Unarvae }}$




\section{TABLE XI}

Acid-cleaned Bullhill Bank sand

\begin{tabular}{|c|c|c|}
\hline \multicolumn{3}{|c|}{ Acid-cleaned Bullhill Bank sand } \\
\hline & $\begin{array}{l}\text { (I) } \\
\text { From storage in } \\
\text { distilled water }\end{array}$ & $\begin{array}{l}\text { Sand as (I) mixed } \\
\text { with charcoal made } \\
\text { from sucrose }\end{array}$ \\
\hline \multicolumn{3}{|c|}{$\begin{array}{l}\text { Settlements.obtained with 5-day-old larvae after } 2 \text { days } \\
\text { A I in free-choice dish }\end{array}$} \\
\hline Metd & None & Fair number \\
\hline Meting & 2 or 3 & Fair number \\
\hline Unmet. & Several & Fair number \\
\hline $\begin{array}{l}\text { Metd } \\
\text { Meting } \\
\text { Unmet. }\end{array}$ & $\begin{array}{l}\text { A } 2 \text { in conical ve } \\
\text { I or } 2 \\
\text { Several } \\
\text { Fair number }\end{array}$ & $\begin{array}{l}\text { Fair number } \\
\text { Fair number } \\
\text { Fair number }\end{array}$ \\
\hline Unmet. & $\mathrm{B}$ in free-choice & \\
\hline Metd & I & $\mathrm{I} 2$ \\
\hline Meting & 4 & I4 \\
\hline Unmet. & 13 & 63 \\
\hline
\end{tabular}

A I and A2 ran concurrently and used larvae from the same fertilization. B was at a later date with larvae from a different fertilization. 